\title{
Do Liquidity, Asset Quality, Firm Size, and Efficiency Affect Bank Profitability? Evidence from Indonesia Stock Exchange
}

\author{
Ni Komang Ardini Febrianti Puteri \\ Department of Magister Management, STIE Perbanas Surabaya, Surabaya \\ e-mail:2018611008@students.perbanas.ac.id
}

\begin{abstract}
Nowadays modern economy cannot be thought without banks. The commercials banks listed on the Indonesia Stock Exchange (IDX) is expected to be a strong and highly competitive bank, which contribute to the growth and even distribution of sustainable regional economies. However, there are still 28 banks that have negative trend in 2019. The purpose of this research is to analyze whether the LDR, NPL, SIZE and BOPO have significant influence simultaneously and partially to ROA commercial banks listed in Indonesia Stock Exchange (IDX). The study followed a descriptive research design and used secondary data obtained from the company annual reports and partly from the commercial banks. There is one basic theory about signaling theory and previous research found some propositions: 1) LDR have significant effect to ROA, 2) NPL have significant effect to ROA, 3) SIZE have significant effect to ROA, 4) BOPO have significant effect to ROA. The implication of this research is expected to be used as consideration in overcoming the problem to improving bank health, especially on bank profitability.
\end{abstract}

Keywords-Liquidity Ratio, Asset Quality Ratio, Firm Size, Efficiency Ratio.

\section{INTRODUCTION}

$\mathrm{T}$ HE banking industry plays an important role such as financial intermediary as regulated by Undang-Undang Republik Indonesia Number 10 in 1998 about banking that says bank is financial institution that the main function are to manage and distribute public funds, which in return support national stability, towards the increase of people's welfare.

Banking profitability is the one of the most important indicators to measure the performance of bank because profitability is an indikator of how banks can be productive. Return on Asset (ROA) it's a ratio to measure bank profitability.

The ROA's formula is to divide the earning before tax with total asset that banks get in the period of time. Banks' health suffers if a ROA bank decreases and if the bank's ROA keeps dropping then the bank could suffer losses. And that's what the commercial banks listed in Indonesia Stock Exchange (IDX) is experiencing right now as seen on Table 1.

Table 1 shows ROA's growth in 2014-2019 that tend to experience downturns, which proven by mean trend $7 \%$. But there's still twenty-eight banks that have negative ROA in the period of time. This shows there is still a problem in profitability of commercial banks listed in Indonesia Stock Exchange. Theoretically the factor that affecting ROA banks can be seen through banks performance like liquidity, quality asset, size, and efficiency.

Liquidity showing the banks management ability to provide funds enough to meet their obligations at all times [1]. Liquidity can be measured by using LDR. According to [1] described that LDR is a ratio used to measure the bank's ability to pay back the withdrawal relying on credits provided as the source of banks liquidity. LDR have a positive impact on the ROA's bank if LDR increasing to total credit in a larger percentage as compared to the percentage of increase in total third party funds, so bank profits are increasing and ROA's bank is increasing. The effect of liquidity on banks profitability is supported by previous studies committed by [2] that liquidity have a positive significant effect to profitability. While research by [3] shows that liquidity have significant effect to profitability.

[4] described productive asset quality shows quality asset related by credit risks that banks faced because of banks give credit and investment funds at a different portfolio. Asset quality can be measured by using NPL ratio. NPL is a ratio used to shows bank management capability in managing credit problems of all the credit given by banks. NPL have a negative impact on the ROA's bank. If NPL has increased which is higher than the increase obtained from total credit, then there will be an increase in costs which has been reserved from bank income, so bank profits and ROA's bank is decreasing. The effect of quality asset on banks profitability is supported by previous studies committed by [3] that asset quality has a significant effect to profitability. While research by [5], [6], and [7] shows that asset quality have a negative effect to profitability.

[8] described firm size used to describe its massive little enterprise indicated by total asset, sales numbers, average sales levels and average total asset. Firm size can be measured by using size ratio. Size have a positive impact on the ROA's bank. The larger the scale of company, profitability will also increase, because of the huge resources the company can make an investment in both good and sustainable assets and also fulfilli the product demand. The effect of size on banks profitability is supported by previous studies committed by [9] that size have a positive significant effect to profitability. Then, the research done by [10] shows that size have a significant effect to profitability. While research by [2] shows that size doesn't have effect to profitability.

Efficiency used for measuring the levels of management performance in using all the factors of production precisely 
The $1^{\text {st }}$ International Conference on Business and Engineering Management (IConBEM)

February $1^{\text {st }} 2020$, Institut Teknologi Sepuluh Nopember, Surabaya, Indonesia

Table 1.

ROA Commercial Banks In Indonesia Stock Exchange Period 2014-2019 (In Percent).

\begin{tabular}{|c|c|c|c|c|c|c|c|c|c|c|c|c|c|}
\hline \multirow{2}{*}{ Code } & \multirow{2}{*}{ Banks Name } & \multicolumn{11}{|c|}{ Year } & \multirow{2}{*}{$\begin{array}{l}\text { Mean } \\
\text { Tren }\end{array}$} \\
\hline & & 2014 & 2015 & Tren & 2016 & Tren & 2017 & Tren & 2018 & Tren & 2019 & Tren & \\
\hline AGRO & Bank Rakyat Indonesia Agroniaga, Tbk & 1.47 & 1.55 & 0.08 & 1.49 & -0.02 & 1.45 & -0.04 & 1.54 & 0.09 & 0.14 & -1.4 & -0.26 \\
\hline AGRS & Bank IBK Indonesia, Tbk & 0.26 & 0.17 & -0.09 & 0.15 & -5.26 & -0.2 & -0.35 & 0.77 & 0.97 & -0.62 & -1.39 & -1.22 \\
\hline ARTO & Bank Artos Indonesia, Tbk & 0.25 & 0.01 & -0.24 & -5.25 & 0.01 & -1.04 & 4.21 & -2.76 & -1.72 & -3.66 & -0.9 & 0.27 \\
\hline BABP & Bank MNC Internasional, Tbk & -0.82 & 0.1 & 0.92 & 0.11 & -0.1 & -7.47 & -7.58 & 0.74 & 8.21 & 0.14 & -0.6 & 0.17 \\
\hline BACA & Bank Capital Indonesia, Tbk & 1.33 & 1.1 & -0.23 & 1 & 0.2 & 0.79 & -0.21 & 0.9 & 0.11 & 0.8 & -0.1 & -0.05 \\
\hline $\mathrm{BBCA}$ & Bank Central Asia, Tbk & 3.9 & 3.8 & -0.1 & 4 & -2.29 & 3.9 & -0.1 & 4 & 0.1 & 3.98 & -0.02 & -0.48 \\
\hline BBHI & Bank Harda Internasional, Tbk & 0.94 & 2.82 & 1.88 & 0.53 & -0.85 & 0.69 & 0.16 & 5.06 & 4.37 & -0.32 & -5.38 & 0.04 \\
\hline BBKP & Bank Bukopin, Tbk & 1.23 & 1.39 & 0.16 & 0.54 & -1.23 & 0.09 & -0.45 & 0.22 & 0.13 & 0.27 & 0.05 & -0.27 \\
\hline BBMD & Bank Mestika Dharma, Tbk & 3.86 & 3.53 & -0.33 & 2.3 & 0.1 & 3.19 & 0.89 & 2.96 & -0.23 & 3.12 & 0.16 & 0.12 \\
\hline BBNI & Bank Negara Indonesia (Persero), Tbk & 3.5 & 2.6 & -0.9 & 2.7 & -0.35 & 2.7 & 0 & 2.8 & 0.1 & 2.51 & -0.29 & -0.29 \\
\hline BBRI & Bank Rakyat Indonesia (Persero), Tbk & 4.73 & 4.19 & -0.54 & 3.84 & 0.15 & 3.69 & -0.15 & 3.68 & -0.01 & 3.42 & -0.26 & -0.16 \\
\hline BBTN & Bank Tabungan Negara (Persero), Tbk & 1.14 & 1.61 & 0.47 & 1.76 & 0.15 & 1.71 & -0.05 & 1.34 & -0.37 & 0.44 & -0.9 & -0.14 \\
\hline BBYB & Bank Yudha Bhakti, Tbk & 0.69 & 1.16 & 0.47 & 2.53 & 1.37 & 0.43 & -2.1 & -2.83 & -3.26 & 0.5 & 3.33 & -0.04 \\
\hline BCIC & Bank JTrust Indonesia, Tbk & -4.97 & -5.37 & -0.4 & -5.02 & 0.35 & 0.73 & 5.75 & -2.25 & -2.98 & 0.38 & 2.63 & 1.07 \\
\hline BDMN & Bank Danamon, Tbk & 1.9 & 1.7 & -0.2 & 2.5 & 0.8 & 3.1 & 0.6 & 3.1 & 0 & 2.53 & -0.57 & 0.13 \\
\hline BEKS & Bank Pembangunan Daerah Banten, Tbk & -1.59 & -5.29 & -3.7 & -9.58 & -4.29 & -1.43 & 8.15 & -1.57 & -0.14 & -2.2 & -0.63 & -0.12 \\
\hline BGTG & Bank Ganesha, Tbk & 0.21 & 0.36 & 0.15 & 1.62 & 1.26 & 1.59 & -0.03 & 0.16 & -1.43 & 1.02 & 0.86 & 0.16 \\
\hline BINA & Bank Ina Perdana, Tbk & 1.29 & 1.05 & -0.24 & 1.02 & -0.03 & 0.82 & -0.2 & 0.5 & -0.32 & 0.19 & -0.31 & -0.22 \\
\hline BJBR & Bank Pembangunan Daerah Jawa Barat \& Banten, Tbk & 1.92 & 2.04 & 0.12 & 2.22 & 0.18 & 2.01 & -0.21 & 1.71 & -0.3 & 1.8 & 0.09 & -0.02 \\
\hline BJTM & Bank Pembangunan Daerah Jawa Timur, Tbk & 3.52 & 2.67 & -0.85 & 2.98 & 0.31 & 3.12 & 0.14 & 2.96 & -0.16 & 3.18 & 0.22 & -0.07 \\
\hline BKSW & Bank QNB Indonesia, Tbk & 1.05 & 0.87 & -0.18 & -3.34 & -4.21 & -3.72 & -0.38 & 0.12 & 3.84 & -0.22 & -0.34 & -0.25 \\
\hline BMAS & Bank Maspion Indonesia, Tbk & 0.82 & 1.1 & 0.28 & 1.67 & 0.57 & 1.6 & -0.07 & 1.54 & -0.06 & 1.15 & -0.39 & 0.07 \\
\hline BMRI & Bank Mandiri (Persero), Tbk & 3.57 & 3.15 & -0.42 & 1.95 & -1.2 & 2.72 & 0.77 & 3.17 & 0.45 & 3.01 & -0.16 & -0.11 \\
\hline BNBA & Bank Bumi Arta, Tbk & 1.52 & 1.33 & -0.19 & 1.52 & 0.19 & 1.73 & 0.21 & 1.77 & 0.04 & 0.9 & -0.87 & -0.12 \\
\hline BNGA & Bank CIMB Niaga, Tbk & 1.33 & 0.47 & -0.86 & 1.09 & 0.62 & 1.7 & 0.61 & 1.85 & 0.15 & 1.84 & -0.01 & 0.1 \\
\hline BNII & Bank Maybank Indonesia, Tbk & 0.68 & 1.01 & 0.33 & 1.6 & 0.59 & 1.48 & -0.12 & 1.74 & 0.26 & 0.82 & -0.92 & 0.03 \\
\hline BNLI & Bank Permata, Tbk & 1.2 & 0.2 & -1 & -4.9 & -5.1 & 0.6 & 5.5 & 0.8 & 0.2 & 1.28 & 0.48 & 0.02 \\
\hline BRIS & Bank BRI Syariah, Tbk & 0.08 & 0.77 & 0.69 & 0.95 & 0.18 & 0.51 & -0.44 & 0.43 & -0.08 & 0.32 & -0.11 & 0.05 \\
\hline BSIM & Bank Sinarmas, Tbk & 1.02 & 0.95 & -0.07 & 1.72 & 0.77 & 1.28 & -0.44 & 0.25 & -1.03 & 0.05 & -0.2 & -0.19 \\
\hline BSWD & Bank of India Indonesia, Tbk & 3.36 & -0.77 & -4.13 & -11.15 & -10.38 & -3.39 & 7.76 & 0.24 & 3.63 & 0.66 & 0.42 & -0.54 \\
\hline BTPN & Bank BTPN, Tbk & 3.6 & 3.1 & -0.5 & 3.1 & 0 & 2.1 & -1 & 3.1 & 1 & 2.25 & -0.85 & -0.27 \\
\hline BTPS & Bank Tabungan Pensiunan Nasional Syariah, Tbk & 4.2 & 5.2 & 1 & 9 & 3.8 & 11.2 & 2.2 & 12.4 & 1.2 & 13.05 & 0.65 & 1.77 \\
\hline BVIC & Bank Victoria International, Tbk & 0.8 & 0.65 & -0.15 & 0.52 & -0.13 & 0.64 & 0.12 & 0.33 & -0.31 & 0.2 & -0.13 & -0.12 \\
\hline DNAR & Bank Oke Indonesia, Tbk & 0.32 & 1 & 0.68 & 0.83 & -0.17 & 0.57 & -0.26 & 0.81 & 0.24 & 0.18 & -0.63 & -0.03 \\
\hline INPC & Bank Artha Graha Internasional, Tbk & 0.79 & 0.33 & -0.46 & 0.35 & 0.02 & 0.31 & -0.04 & 0.27 & -0.04 & 0.21 & -0.06 & -0.12 \\
\hline MAYA & Bank Mayapada Internasional, Tbk & 1.98 & 2.1 & 0.12 & 2.03 & -0.07 & 1.3 & -0.73 & 0.73 & -0.57 & 1.08 & 0.35 & -0.18 \\
\hline MCOR & Bank China Construction Bank Indonesia, Tbk & 0.79 & 1.03 & 0.24 & 0.69 & -0.34 & 0.54 & -0.15 & 0.86 & 0.32 & 0.46 & -0.4 & -0.07 \\
\hline MEGA & Bank Mega, Tbk & 1.16 & 1.97 & 0.81 & 2.36 & 0.39 & 2.24 & -0.12 & 2.47 & 0.23 & 2.75 & 0.28 & 0.32 \\
\hline NAGA & Bank Mitraniaga, Tbk & 0.59 & 0.71 & 0.12 & 0.76 & 0.05 & 0.37 & -0.39 & 0.51 & 0.14 & -0.62 & -1.13 & -0.24 \\
\hline NISP & Bank OCBC NISP, Tbk & 1.34 & 1.3 & -0.04 & 1.88 & 0.58 & 1.96 & 0.08 & 2.1 & 0.14 & 2.24 & 0.14 & 0.18 \\
\hline NOBU & Bank Nationalnobu, Tbk & 0.43 & 0.38 & -0.05 & 0.52 & 0.14 & 0.48 & -0.04 & 0.42 & -0.06 & 0.49 & 0.07 & 0.01 \\
\hline PNBN & Bank Pan Indonesia, Tbk & 2.23 & 1.31 & -0.92 & 1.69 & 0.38 & 1.61 & -0.08 & 2.16 & 0.55 & 2.01 & -0.15 & -0.04 \\
\hline PNBS & Bank Panin Dubai Syariah, Tbk & 1.99 & 1.14 & -0.85 & 0.37 & -0.77 & -10.77 & -11.14 & 0.26 & 11.03 & 0.16 & -0.1 & -0.37 \\
\hline SDRA & Bank Woori Saudara Indonesia 1906, Tbk & 2.81 & 1.94 & -0.87 & 1.93 & -0.01 & 2.37 & 0.44 & 2.59 & 0.22 & 2.2 & -0.39 & -0.12 \\
\hline & Mean Trend & 1.42 & 1.19 & -0.23 & 0.65 & -0.54 & 0.89 & 0.24 & 1.45 & 0.56 & 1.23 & -0.22 & -0.04 \\
\hline
\end{tabular}

and productively. This ratio measure how efficient bank's using their operating costs. Efficiency can be measured by using operational efficiency ratio. [1] describe that operational efficiency ratio is used to measure operational costs and non-operational costs that banks used to make profits. Operational efficiency ratio have a negative impact to banks profitability if operational efficiency ratio gets a higher increase in bank operating expenses compared to non-interest 
The $1^{\text {st }}$ International Conference on Business and Engineering Management (IConBEM)

February $1^{\text {st }} 2020$, Institut Teknologi Sepuluh Nopember, Surabaya, Indonesia

operating income and non-interest operating costs, so bank profits are increasing and ROA's bank is increasing. The effect of operational efficiency on banks is supported by previous studies committed by [3] that efficiency have a significant effect to profitability. Then, the research done by [11] shows that efficiency have a negative impact to profitability. While research by [6] and [7] shows that efficiency have a negative significant impact to profitability.

\section{THEORITICAL REVIEW}

Signaling Theory. Is a theory that emphasizes the importance of information, any information released by the company will matter towards decision to be made by management or paries outside the company. This research using signaling theory because to link between management and information. One type of information given by the bank is bank financial statement issued either monthly, quarterly, or annually.

Bank Financial Performance. Bank financial performance can be seen on the financial statements of a bank in each period. Bank profitability is very important because for measuring and knowing the performance of a bank.

Profitability. Is a ratio that is used to measure the efficiency levels of business and profitability achieved by bank. Profitability ratio can be used for measure the bank's financial health level to raise sufficient levels [12].

Return on Asset (ROA). According to [1] ROA is a ratio used to measure banks' overall profitability. Profit obtained from earning before tax obtained by a bank is the net profit derived from operational activities which makes pre-tax returns. Total asset is the average volume of business or assets over the past twelve months. ROA can be calculated by using this following formula:

$$
\text { ROA }=\frac{\text { earning before tax }}{\text { total asset }} \times 100 \%
$$

Liquidity. Liquidity defined as bank management's ability to provide sufficient funds to fulfilling the obligation every time [1].

Loan to Deposit Ratio (LDR). LDR is a ratio used to measure the bank's ability to pay back the withdrawal relying on credits provided as the source of banks liquidity. The higher LDR giving low indications of the banks liquidity abilities [1]. Credit given is the total credit given by the bank to the third party (excluding credit to other banks). The third parties total fund consists of giro, savings and deposits (not including among banks). LDR can be calculated by using this following formula:

$$
\mathrm{LDR}=\frac{\text { total loans }}{\text { total deposit to equity }} \times 100 \%
$$

Asset Quality. According to [4] productive asset quality shows quality asset related by credit risks that banks faced because of banks give credit and investment funds at a different portfolio. Asset quality or earning asset are all assets in rupiah and foreign exchange owned by banks with the intent of earning according to its function. Fund management in earning assets is a source of bank income used to finance the entire banks operational costs, including interest costs, labor costs, and other operational costs.

Non-Performing Loan (NPL). NPL is a ratio used to shows bank management capability in managing credit problems of all the credit given by banks. Components of NPL consists good, poor, and very poor. NPL are calculated on gross basis (not reduced by Provision for Loan Losses). The total credit component consists of the amount of credit to third parties for related or unrelated parties. NPL can be calculated by using this following formula:

$$
\mathrm{NPL}=\frac{\text { non performing loans }}{\text { total loans }} \times 100 \%
$$

Firm Size. Firm size used to describe its massive little enterprise indicated by total asset, sales numbers, average sales levels and average total asset [8]. Size can be calculated by using this following formula:

$$
\text { SIZE }=\text { Ln Total Asset }
$$

Efficiency. Efficiency used for measuring the levels of management performance in using all the factors of production precisely and productively. This ratio measure how efficient bank's using their operating costs.

Operational efficiency ratio. Operational efficiency ratio is used to measure operational costs and non-operational costs that banks used to make profits. Components of operating expenses consist of interest expenses and operating expenses other than interest. The component of operating income consists of interest income and operating income other than interest. Operational efficiency ratio can be calculated by using this following formula:

$$
\text { Operational Efficiency Ratio }=\frac{\text { Operational Cost }}{\text { Net Sales }} \times 100 \%
$$

\section{METHOD}

The paper is conceptual and qualitative in nature. This study examines 8 previous studies that discussed the effect of liquidity, asset quality, size, and efficiency on banks profitability.

\section{DISCUSSION}

From the explanation of the foundation of banking theory that will be examined and the results of the previous research being referenced have been obtained from the research framework about the impact of independent variables which in this research used four independent variables, LDR, NPL, SIZE and Operational Efficiency Ratio which can be seen more clearly in figure 1 about the the framework of thought which will be used in research conducted this time.

The effect of liquidity on banks profitability is supported by previous studies committed by [2] that liquidity have a positive significant effect to profitability. While research by [3] shows that liquidity have significant effect to profitability. The effect of quality asset on banks profitability is supported by previous studies committed by [3] that asset quality has a significant effect to profitability. While research by [5], [6], 


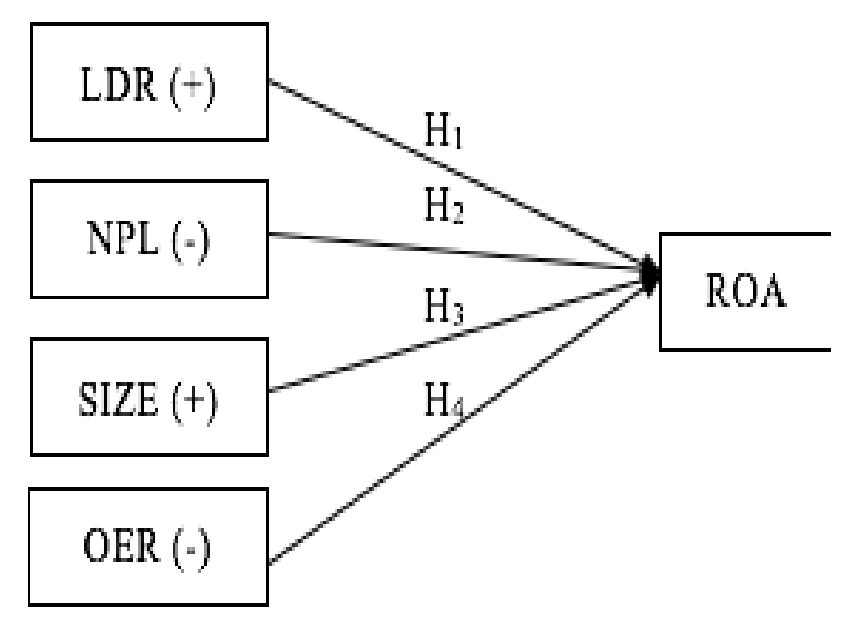

Figure 1. Framework.

Notes:

LDR : Loan to Deposit Ratio

NPL : Non-Performing Loan

SIZE : Firm Size

OER : Operational Efficiency Ratio

and [7] shows that asset quality have a negative effect to profitability. The effect of size on banks profitability is supported by previous studies committed by [9] that size have a positive significant effect to profitability. Then, the research done by [10] shows that size have a significant effect to profitability. While research by [2] shows that size doesn't have effect to profitability. The effect of operational efficiency on banks is supported by previous studies committed by [3] that efficiency have a significant effect to profitability. Then, the research done by [11] shows that efficiency have a negative impact to profitability. While research by [6] and [7] shows that efficiency have a negative significant impact to profitability.

Based on the introduction, method, framework and discussion, the hypothesis proposed in this research is:

H1: Liquidity have a significant effect to profitability on commercial banks listed in Indonesia Stock Exchange.

H2: Asset quality have a significant effect to profitability on commercial banks listed in Indonesia Stock Exchange.

H3: Size have a significant effect to profitability on commercial banks listed in Indonesia Stock Exchange.

H4: Efficiency have a significant effect to profitability on commercial banks listed in Indonesia Stock Exchange.

\section{RESULT}

\section{A. The Effect of Liquidity to Banks Profitability}

LDR has a positive impact on ROA. LDR improves the increase, then indicates an increase in the amount of credit given by banks by a greater percentage than the percentage increase in third party funds, as a result an increase in interest income that is greater than an increase in interest costs, increases bank income increases and ROA of a bank will increase.

The effect of LDR on ROA has been proven by [2] with the results of LDR research having a positive effect on profitability. Research conducted by [3] results in LDR having a significant effect on profitability.

\section{B. The Effect of Asset Quality to Banks Profitability}

NPL has a negative impact on ROA. This can happen if the NPL increases, an increase in non-performing loans with a percentage level greater than the percentage increase in total credit, as a result an increase in fees reserved is greater than the increase in income, so that bank profits decline and ROA of a bank will also decrease.

The effect of NPL on ROA has been proven by [5] with the results of NPL research having a negative effect on profitability. Research conducted by [6] and [7] has NPL results which have a significant negative effect on profitability.

\section{The Effect of Size to Banks Profitability}

Size has a positive effect on ROA. This can happen because if the total assets of a large bank can increase market confidence and large assets can be used in bank operations, especially lending so that it has a positive effect on increasing profitability, resulting in an increase in revenue that is greater than the total assets, so that profits banks increase and ROA of a bank will increase.

The effect of Size on ROA has been proven by [9] which produces a size that has a significant positive effect on profitability.

\section{The Effect of Efficiency to Banks Profitability}

BOPO has a negative impact on ROA. This can happen if the BOPO increases, an increase in operational costs is greater than the increase in bank operating income, this causes the costs incurred by the bank is greater than the income received by the bank, resulting in decreased bank profits and ROA of a bank also decreases.

The effect of BOPO on ROA has been proven by [11] which results in BOPO having a negative effect on profitability. Research conducted by [10] and [7] results in a BOPO that has a significant negative effect on profitability.

\section{CONCLUSION}

It can be concluded that it is important to see the profitability to banks performance. Considering that the banking industry plays an important role such as financial intermediary as regulated by Undang-Undang Republik Indonesia Number 10 in 1998 about banking that says bank is financial institution that the main function are to manage and distribute public funds, which in return support national stability, towards the increase of people's welfare.

\section{REFERENCES}

[1] V. Rivai, Commercial Bank Management Manajemen Perbankan, Jakarta: PT Raja Grafindo Persada, 2013.

[2] C. O. Zaman and Musdholifah, "Pengaruh Faktor Internal, Makroekonomi, dan Konsentrasi Pangsa Pasar terhadap Profitabilitas Bank Umum Konvensional di Indonesia Periode 2012-2016," Jurnal Ilmu Manajemen, vol. 6, pp. 213-226, 2018.

[3] E. Sudarmawanti and J. Pramono, "Pengaruh CAR, NPL, BOPO, NIM dan LDR terhadap ROA (Studi Kasus pada Bank Perkreditan 
The $1^{\text {st }}$ International Conference on Business and Engineering Management (IConBEM)

February $1^{\text {st }} 2020$, Institut Teknologi Sepuluh Nopember, Surabaya, Indonesia

Rakyat di Salatiga yang terdaftar di Otoritas Jasa Keuangan Tahun 2011-2015)," Jurnal Ilmiah Among Makarti, pp. 1-18, 2017.

[4] M. Kuncoro, "Manajemen Perbankan Teori dan Aplikasi," in Manajemen Perbankan Teori dan Aplikasi, Yogyakarta, BPFEYogyakarta, 2015, p. 519.

[5] S. Alshatti, "Determinants of Bank's Profitability - the case of Jordan," Investment Management and Financial Innovations, vol. 13, no. 1, pp. 84-91, 2016.

[6] M. Nohong, "Strategi Environment and Bank Performance (Empirical Study of Bank Listed in Indonesian Stock Exchange period 2011-2015)," Journal of Economics, Business, and Accountancy Ventura, vol. 19, pp. 325-334, 2017.

[7] V. W. Widajatun and S. Ichsani, "The Impact of Credit, Liquidity, Operational and Market Risks on Return on Asset," Global Business and Management Research: An International Journal, vol. 11, no. Special Issue, pp. 335-340, 2019.
[8] Solechan, Pengaruh Earning, Manajemen Laba, IOS, BETA, SIZE, dan Rasio Hutang terhadap Return Saham pada Perusahaan yang Go Public di BEI, Semarang: STMIK HIMSYA, 2006.

[9] T. Yahya, A. Akhtar and M. I. Tabash, "The Impact of Political Instability, Macroeconomic and Bank-Spesific Factors on the Profitability of Islamic Banks: an Empirical Evidence," Investment Management and Financial Innovations, vol. 14, no. 4, pp. 30-39, 2017.

[10] S. Parvin and A. S. J. F. A.N.M. Minhajul Haque Chowdury, "Effect of Liquidity and Bank Size on the Commercial Banks in Bangladesh," Asian Business Consortium, pp. 7-10, 2019.

[11] Lemiyana and E. Litriani, "Pengaruh NPF, FDR, BOPO terhadap Return on Asset (ROA) pada Bank Umum Syariah," I-Economic, vol. 2, pp. 31-49, 2016.

[12] Kasmir, Bank dan Lembaga Keuangan Lainnya Edisi Revisi 2014, Jakarta: PT Raja Grafindo Persada, 2014. 